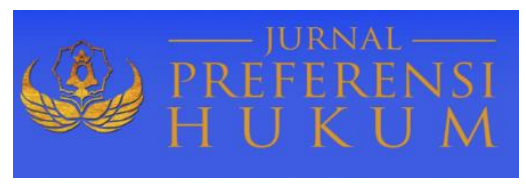

Jurnal Preferensi Hukum | ISSN: XXXX | E-ISSN: XXXX

Vol. 1 No 1 - Juli 2020 hal. 243-248| Available online at https://www.ejournal.warmadewa.ac.id/index.php/juprehum

\title{
REHABILITASI TERHADAP KORBAN PENYALAHGUNAAN NARKOTIKA DI BADAN NARKOTIKA NASIONAL PROVINSI BALI
}

\author{
I Made Subantara, A. A. Sagung Laksmi Dewi, Luh Putu Suryani \\ Fakultas Hukum Universitas Warmadewa, Denpasar-Bali, Indonesia
}

\begin{abstract}
Abstrak
Narkotika terus diproduksi pada saat ini di samping untuk pengobatan juga untuk pengembangan studi ilmiah. Narkotika, disatu sisi, merupakan obat atau bahan yang berguna di bidang kedokteran atau layanan Kesehatan dan pengembangan ilmu pengetahuan, dilain pihak, bias mengakibatkan ketergantungan dan menyebabkan kerugian jika tidak di pergunakan dengan benar serta tanpa control dan pengawasan yang ketat dan berhati-hati. Ketika digunakan secara tidak teratur sesuai dosis, dapat merusak fisik dan mental bagi mereka yang menggunakannya menjadi ketergantungan. Penelitian ini bertujuan untuk mengetahui prosedur pelaksanaan rehabilitasi terhadap korban penyalahgunaan narkotika dan kendala-kendala yang di hadapi Badan Narkotika Nasional Provinsi Bali dalam merehabilitasi penyalahgunaan narkotika di Badan Narkotika Nasional Provinsi Bali. Penelitian ini menggunakan metode normative di karenakan masih terdapat norma yang kabur, dengan bersumber pada pendapat parasarjana hokum dan Undang-Undang.
\end{abstract}

Kata Kunci: Narkotika Penyalahgunaan; Rehabilitasi

\begin{abstract}
Narcotics continues to be produced at this time in addition to medicine as well as for the development of scientific studies. Narcotics, on the one hand, is a drug or substance that is useful in the field of medicine or health services and scientific development, on the other hand, it can lead to dependence and cause harm if it is not used properly and without strict and careful control and supervision. When used irregularly according to dosages, it can be physically and mentally damaging for those who use it to become dependent. This study aims to determine the procedures for implementing rehabilitation of victims of narcotics abuse and the obstacles faced by the National Narcotics Agency of Bali Province in rehabilitating narcotics abuse at the National Narcotics Agency of Bali Province. This research uses the normative method because there are still vague norms, based on the opinion of the undergraduate law and law.
\end{abstract}

Keywords: Narcotics Abuse; Rehabilitation

\section{PENDAHULUAN}

Negara hokum pada dasarnya bertujuan untuk memberikan perlindungan hokum bagi rakyat (Harap,2002). Perlindungan hokum yang dimaksud yaitu perlindungan terhadap serangkaian Tindakan pemerintah yang berlandaskan pada 2(dua) prinsip, yaitu prinsip hak asasi manusia dan prinsip negara hukum. Dapat dikatakan bahwa hokum tidak boleh statis, melainkan harus dinamis, serta selalu diadakan perubahan sejalan dengan perkembangan zaman serta dinamika kehidupan social dalam masyarakat (Suyanto,2013).

Saat ini, narkotika dibutuhkan guna perawatan, sehingga dibutuhkan obat-obat anguna penelitia nilmiah, pasien-pasien ini memerlukan produksi narkotika secara terus menerus. Mengingat undangundang 35 tahun 2009 tentang narkotika, dinyatakan bahwa narkotika adalah obat atau bahan yang berguna di bidang kedokteran atau layanan kesehatan dan pengembangan ilmiah, di satu sisi, dan bahwa itu juga dapat menyebabkan ketergantungan yang sangat berbahaya dalam kasus penyalah gunaan atau digunakan tanpa control dan pengawasan yang ketat dan hati-hati (Iskandar, 2019). Ini berarti ada keinginan psikologi yang sangat kuat untuk menggunakan obat secara terus menerus karena penyebab emosional. Usaha untuk 
mengembalikan kondisi atau posisi dari masalah yang berhubungan dengan orang kecanduan terhadap sesuatu yang dapat merusak saraf dan darah manusia itu sendiri tidaklah pekerjaan mudah.

Namun melihat kondisi masalah narkoba di Provinsi Bali semakin memprihatinkan oleh Badan Narkotika Nasional Provinsi (BNNP) terus berupaya membersihkan bahkan membebaskan Bali khususnya dan Indonesia pada umumnya bebas dari narkoba. Untuk mewujudkan Indonesia yang bebas narkoba, BNNP telah menyatakan tahun 2014 sebagai tahun untuk menyelamatkan penyalahgunaan narkoba. Ini dilakukan sebagai Langkah antisipatif untuk mengurangi penyalahgunaan narkoba. Ini dilakukan sebagai langkah antisipatif untuk mengurangi penyalahgunaan narkoba karena penyalahgunaan narkoba meningkat setiap tahun. Saat ini, jumlah penyalahgunaan narkoba di Indonesia telah meningkat menjadi $2.3 \mathrm{juta}$. Untuk ini kita perlu langkah konkret untuk mengurangi jumlah penyalahgunaan narkoba.

Jadi masyarakat dan apparat penegak hokum sendiri, penggunaan narkoba dianggap sebagai tindak akan pidana yang harus dijatuhi hukuman penjara. Selain itu, salah satu bentuk sanksi tindakan adalah rehabilitasi (Krisnawati \& Utami, 2015). Akan tetapi hingga saat ini, rehabilitasi mengalami banyak kendala, penelitian terdahulu tentang rehabilitasi sosial terhadap pecandu narkoba anak di bawah umur di yayasan kelompok peduli penyalahgunaan narkotika dan obat-obatan terlarang Makassar mengungkapkan jika kendala yang dihadapi YKP2N dalam melaksanakan rehabilitasi sosial antara lain kurangnya dukungan dari orangtua klien, belum adanya penerimaan diri yang dimiliki klien dan terbatasnya sumber daya manusia yang ada (Ernawati \& Tahir, 2017). Penelitian terdahulu lainnya tentang implementasi proses rehabilitasi terhadap penyalahguna narkotika di panti rehabilitasi Yayasan Anargya Bali menyatakan bahwa hambatan dalam proses rehabilitasi terhadap penyalahguna narkotrika di Yayasan Anargya Bali terdiri dari factor intern dan factor ekstern (Hariwangi, Nahak, \& Sukadana, 2019). Banyak studi mengkaji tentang tidak hanya kendala ataupun hambatan yang ditemui, tetapi juga acuan pelaksanaanya. Salah satu studi yang dimaksud adalah penerapan sanksi rehabilitasi terhadap pengguna dan korban penyalahgunaan narkotika, dijelaskan bahwa pelaksanaan rehabilitasi terhadap korban penyalahgunaan narkotika di pusat rehabilitasi Narkotika Baddoka Kota Makassar sudah sesuai dengan apa yang diamanahkan oleh UndangUndang Nomor 35 Tahun 2009 Tentang Narkotika. Adapun juga kendala pelaksanaan rehabilitasi terhadap para pecandu atau penguna narkotika yaitu kurangny apengetahuan masyarakat khususnya para keluarga pecandu narkotika (Pananjung \& Akbar, 2014). Penelitian tentang efektifitas rehabilitasi pecandu narkotika melalui terapi islamidi Badan Narkotika Nasional (BNN) Banda Aceh menunjukkan bahwa efektifitas rehabilitasi Narkoba di BNNP Aceh yang harus dilalui oleh korban penyalahguna narkoba adalah Screening dan Intake, Detoksifikasi, EntryUnit, Primary Program, Re-Entrydam Pasca Rehabilitasi (Bakri \& Barmawi, 2017).

Tidak hanya sampai disitu, situasi ini mengarah kemasalah lain, seperti beban lembaga pemasyarakatan, yang kemudian disingkat menjadi kelebihan kapasitas, sementara penjara menjadi tempat Yang aman untuk penggunaan narkoba dan munculnya tindakan criminal lainnya yang disebabkan oleh pengunaan narkoba di penjara, selain perdagan narkoba bahkan dipenjara. Menemukan produksi narkoba dipenjara. Narkotika memengaruhi fisik dan mental ketika digunakan pada dosis yang benar dan dibawah pengawasan ahli enestesi atau dokter, narkotika dapat digunakan untuk tujuan pengobatan atau penelitian sehingga bermanfaat bagi kesehatan fisik dan metal manusia. Sedangkan untuk kelompok narkotika, opium dan komponen aktifnya, yaitu morfin, heroin, kodein, ganja dan kokain, adalah hash, metam fetamin, koplo dan sejenisnya.

Masalah narkotika menjadi masalah yang serius dan memprihatinkan pada beberapa tahun terakhir ini. Korba penyalahgunaan menjadi semakin banyak sampai pada batas-batas sosial dan jenis kelamin. Penyebarannya sampai kependesaan tidak lagi di perkotaan saja, hal semakin menyababkan negara menjadi rugi dan nilai budaya rusak dan pada akhirnya ketahanan negara menjadi lemah. Oleh karena itu, penelitia ini bertujuan untuk mengetahui prosedur pelaksanaan rehabilitasi terhadap korban penyalahgunaan narkotika dan kendala-kendala yang dihadapi Badan Narkotika Nasional Propinsi Bali dalam merehabilitasi penyalahgunaan narkotika di Badan Narkotika Nasional Propinsi Bali. 


\section{METODE PENELITIAN}

Jenis penelitian ini adalah penelitian hokum empiris. Penelitian ini menggunakan metode normative di karenakan masih terdapat norma yang kabur, dengan bersumber pada pendapat parasarjana hokum dan undang-undang. Sumber data diperoleh dari hasil wawancara dengan Klinik Pratama Badan Narkotika Nasional Propinsi Bali yang menganangi pelaksanaan rehabilitasi terhadap korban penyalahgunaan narkotika. Data terkumpul lalu dianalisis secara deskriptif kualitatif.

\section{HASIL DAN PEMBAHASAN}

Masyarakat semakin menyadari mengenai besarnya ancaman yang dihadapi pada saat ini dan waktu kedepannya, yaitu semakin meningkatnya penyalahgunaan dan Perdagangan gelap narkoba di Indonesia telah meningkat, menargetkan generasi muda dan bahkan memasuki akademisi, yaitu pelajar (Nasional, n.d.).

Rehabilitasi adalah suatu bentuk hukuman yang ditujukan untuk pemulihan atau perawatan. Apabila orang yang bersangkutan dapat dibuktikan atau terbukti sebagai korban penyalahgunaan narkotika, maka harus menjalani rehabilitasi medis maupun rehabilitasi sosial (Purwani, Darmadi, \& Putra, 2016). Rehabilitasi adalah fasilita setengah tertutup, yang berarti hanya orang-orang tertentu yang memiliki minat khusus yang dapat memasuki area ini (Soeparman,2000). Rehabilitasi narapidana adalah tempat dimana pelatihan keterampilan dan pengetahuan disediakan untuk menghindari narkotika.

Rehabilitasi, oleh pemerintah dalam Undang-Undang Narkotika juga telah memasukkan ketentuan rehabilitasi yang dapat dilihat pada Pasal 54 Undang-Undang Nomor 35 tahun 2009 tentang Narkotika (Putra, 2016). Pada pasal 54 diatur bahwa pecandu dan korban penyalahgunaan narkotika wajib menjalani rehabilitasi (Franti, 2016). Melaksanakan terapi dan rehabilitasi bagi pecandu narkotika menjadi penting mengingat peningkatan jumlah korbannya, sehingga diperlukan terobosan supaya langkah tersebut menjadi efektif. Sistem penjara yang menekankan unsur-unsur pencegahan dan penggunaan tempat tahanan sebagai individu hanya dilihat sebagai tidak sesuai dengan kepribadian bangsa Indonesia berdasarkan Pancasila dan UUD 1945 (Sujatno,2008).

Berbagai bentuk atau metode dalam pelaksanaan rehabilitasi pengguna narkoba, dalam hal ini narapidana pengguna narkoba, seperti rehabilitasi medis, rehabilitasi, tetapi dalam pelaksanaan rehabilitasi dan metode medis digabungkan menjadi satu, sehingga pada tahap ini proses pemulihan empat tahap bagi pengguna narkoba, yaitu tahap pemeriksaan kesehatan. Seorang dokter dan perawat memiliki peran yang sangat penting dalam pemeriksaan awal apakah pasien/napi dalam keadaan sehat atau tidak, riwayat penyakit yang telah diderita dan kemudian semua data karakteristik fisik kesehatan nya dicatat dalam rekam medis. Tahap detoksifikasi, terapi bebas obat dan terapifisik bertujuan untukmengurangi dan menghilangkan racun dari tubuh, mengurangi efek Penarikan obat dan mengobati komplikasi mental pasien. Ada beberapa cara seperti coldturkey (berbicara terus terang tentang hal-hal yang tidak menyenangkan), konvensional (gejala), penggantian (penggantian sumber daya). Tahap stabilitas mental dan emosional pasien, sehingga gangguan mental yang menyebabkan penyalahgunaan narkoba dapat diatasi. Pada tahap ini, dilakukan dengan melibatkan sejumlah keahlian, seperti pengawas dan pengawas dan psikolog, yaitu melalui metode kerja sosial, konseling sosial dalam bentuk terapi individu dilakukan untuk mengungkapkan atau memecahkan masalah dasar yang dialami oleh narapidana. Sehingga mereka dapat membantu dalam proses rehabilitasi selanjutnya. Selain itu, solusi alternative untuk masalah yang dihadapi oleh pasien/tahanan sedang dicari. Metode ini dilakukan secara tatap muka antara petugas utama dan tahanan.

Sementara prosedur untuk mengajukan permintaan rehabilitasi narkoba untuk pecandu, dalam kasus pecandu yang dibawah umur, orangtuanya yang belum tua harus melaporkan kepetugas kesehatan masyarakat, rumah sakit dan/atau lembaga rehabilitasi medis dan sosial yang ditunjuk oleh pemerintah untuk menerima perawatan dan/atau perawatan melalui rehabilitasi medis dan rehabilitasi sosial. Jika pecandu narkoba sudah cukup umur, pecandu narkoba harus melaporkan atau dilaporkan oleh keluarga mereka kepusat-pusat komunitas, rumah sakitdan/atau lembaga rehabilitasi medis dan sosial yang ditunjuk oleh pemerintah untuk menerima perawatan dan/atau perawatan melalui rehabilitasi medis dan rehabilitasi sosial. Prosedur untuk permintaan rehabilitasi dalam konteks pertanyaan tentang permintaan rehabilitasi 
dengan pengadilan, permintaan untuk diajukan kepada Jaksa Penuntut (tingkat penuntutan) atau Hakim (tingkat ujian). Jaksa penuntut umum menuntut dan hakim bertugas memeriksa dipersidangan kemudian bias minta dukungan dari tim penilai terintegrasilokal untuk menilai terhadap terdakwa. Dukungan penilaian ini dilaksanakan menurut peraturan BNN 11 tahun 2014 dan hasilnya diperlihatkan kepada jaksa atau hakim melalui laporan resmi tentang penyerahan hasil penilaian.

Petugas sudah menegakkan hokum pada pemakai narkotika Dan tidak sedikit yang telah menerima putusan. Oleh karena itu, penegakan hokum diharapkan dapat menjadi penawar terhadap penyebaran perdagangan gelap dan distribusi narkotika. Namun pada kenyataannya, penegakan hokum yang lebih intensif sedang dilakukan, meningkatnya perdagangan narkotika dan narkotika. Ketentuan hokum tentang narkotika telah disiapkan dan ditegakkan, tetapi kejahatan terkait narkoba tidak dapat diberantas. Dalam banyak kasus baru-baru ini, banyak bandar udara dan dealer ditangkap dan diberi sanksi berat, tetapi factor lain, seperti mengabaikan mereka, bahkan lebih mungkin untuk memperluas cakupan mereka (Kaligis \& Associates, 2002).

Hambatan yang dihadapi BNN dalam mencegah penyalahgunaan narkoba termasuk hambatan untuk harmonisasi berbagai lembaga yang bekerja secara sinergis dengan BNN/Kota. Dana terbatas, partisipasi masyarakat rendah, dan pembatasan dalam sarana dan prasarana. Pembatasan yang ditujukan dalam pengobatan narkotika, termasuk alokasi sumber daya untuk pelaksanaan tindakan pencegahan minimal, fasilitas laboratorium yang tidak memadai, kesadaran public yang tidak memadai untuk memberikan informasi tentang distribusi obat-obatan narkotika dan penyalahgunaan yang mereka ketahui, kurangnya fasilitas dan Infrastruktur untuk menyelidiki perdagangan gelap dan penyalahgunaan narkoba.

Selain itu, karena kurangnya partisipasi masyarakat, masyarakat tidak memiliki pemahaman tentang tugas Badan Narkotika Nasional, karena orang akan dianggap tahu jika memakai narkoba karena orangorang malu bahwa keluarga mereka terkait dengan narkoba disamping masalah-masalah ini. Badan Narkotika Nasional telah dipaksa untuk menangkap pengguna narkoba, kurangnya rehabilitasi, ketakukan dari pihak keluarga anaknya ditangkap, pada hal sebenarnya ditangkap tidak berarti mereka berada dipenjara, namun untuk direhabilitasi dan rawat jalan, inilah sebabnya BNN terbatas mengambil tindakan keras terhadap penggunanya, karena ketidak mauan pihak keluarga membantu petugas. Masyarakat masih asing dengan undang-undang untuk pengguna narkoba, dan beberapa orang masih bingung dengan peraturan perundangan terkait narkoba. Terdapat pembatasan mengkonsumsi narkoba sebanyak 3,5 gram, jika kurang dari itu perlu dipulihkan. Kekurangan aparat, kurangnya hibah pemerintah, maka program rehabilitasi menjadi tidak maksimal, karena program rehabilitasi tidak disusun setiap tahun, jika program rehabilitasi tidak selesai, pengguna narkoba yang direhabilitasi tidak memiliki tempat, dan jika ditangkap oleh polisi, tidak semua polisi tahu kemana harus pergi, harus ada proses hokum yang terintegrasi, dari pihak medis dan pihak hokum bersama-sama untuk menyimpulkan apa yang perlu dilakukan, karena pengguna akan direhabilitasi sementara untuk distribusi diberikan criminal dan direhabilitasi, rehabilitasi terganggu pada periode penahanan. Pengguna narkoba tidak mau mengaku, meskipun bukti sudah ditemukan, kurangnya bimbingan, sosialisasi, dan lembaga pemulihan masih sedikit.

Kontribusi masyarakat untuk mengatasi narkotika, karena masih ada orang yang tidak mau repot atau malu melaporkan keluarga mereka yang menggunakan narkoba ke BNN. Lalu ada orang yang mengatakan itu cukup baik, tetapi masih ada orang yang tidak menyadari tugas utama dan fungsi Badan Narkotika Nasional itu sendiri, umumnya orang-orang kurang berpengetahuan disbanding program pemerintah lain semacam keluarga berencana. Ada, tetapi masih ada, baik dalam hal pelaporan dan dalam fase penyembuhan keluarganya dirawat, adaorang-orang yang berpikir bahwa jika mereka dirawat dirumah sakit/direhabilitasi, itu seperti membuang keluarga mereka. Keterbatasan fasilitas dan infrastruktur dalam mengatasi penyalah gunaan narkoba, staf ditempat yang tidak memadai, alokasi sumber daya untuk melaksanakan tindakan pencegahan sangat minim, terutama dalam konseling, penjangkauan dan upayaupaya lainnya mendukung implementasi penanggulangan ini.

Hambatan lainnya ditemui antara lain tenaga kesehatan masih kurang, alat tes urin minim (kurang memadainya perlengkapan laboratorium) masyarakat kurang sadar untuk bekerjasama dengan BNN jika menemukan transkasi narkotika. Sehingga langkah yang diambil supaya biar teratasinya kendala tersebut dengan selalu mempererat komunikasi dan menyiagakan satuan keamanan yang terkoordinasi untuk 
melaksanakan penelitian, mengusahakan dukungan dana dari pihak lain baik di desa maupun kecamatan sehingga masalah peredaran narkotika bias diatasi.

\section{SIMPULAN DAN SARAN \\ 1. Simpulan}

Berdasarkan hasil analisis diatas, maka dapat disimpulkan bahwa upaya memberikan rehabilitasi bagi penyalahgunaan tindakpidana narkotika antara lain dengan cara melakukan pembinaan yang berguna untuk membantu seseorang melepaskan diri dari penyalahgunaan narkotika, melatih kemampuan dan kreatifitas pecandu yang dimiliki guna mengalihkan perhatian dari obat-obatan terlarang dengan adanya pengisian waktu luang yang memiliki dampak positif dengan mengikuti siraman rohani dan pendekatan kembali terhadap Tuhan Yang Maha Esa serta penerapan hidup sehat dengan berolahraga. Pelaksanaan rehabilitasi dalam tahap pemeriksaan dikepolisian ataupun pada proses peradilan bagi korban penyalahgunaan narkotika memiliki mekanis meter sendiri. Tujuan rehabilitasi sebagai tahap pemulihan bagi penyalahgunaan narkoba dilaksanakan dengan pembinaan. Kemudian, peran Badan Narkotika Nasional, ketika menyangkut, antara lain, pencegahan narkotika, adalah untuk menetapkan dan menerapkan kebijakan nasional tentang pencampuran dan pencegahan dan penghapusan penyalahgunaan dan penyebaran obat-obatan narkotika dan precursor narkotika sumber daya. Hambatan yang dihadapi BNN dalam mencegah penyalah gunaan narkoba termasuk hambatan untuk harmonisasi berbagai lembaga yang bekerja secara sinergis dengan BNN/Kota. Dana terbatas, partisipasi masyarakat rendah, dan pembatasan dalam sarana dan prasarana. Pembatasan yang diatasi dalam penanganan narkotika, termasuk alokasi sumber daya untuk menerapkan tindakan pencegahan minimal, fasilitas laboratorium yang tidak memadai, kurangnya kesadaran masyarakat untuk memberikan informasi sirkulasi diluar penyalahgunaan narkotika yang mereka tahu, kurangnya fasilitas diluar infrastruktur untuk meningkatkan sirkulasi Penyakit Gela patas penyalahgunaan zat.

\section{Saran}

Melalui penelitian ini diharapkan bagi pemerintah sebagai pejabat berwenang wajib mengkaji ulang ketentuan dari KUHP terkait sanksi pidana yang mengatur khususnya mengenai narkotika, agar segala sesuatu bentuk tindakan yang menyimpang tidak terjadi lagi. Kemudian, bagi BNN sebagai Badan yang menangani suatu kasus narkotika untuk menyelidiki lebih dalam lagi mengenai suatu penyeludupan yang dilakukan antara apparat penegak hokum yang berada di LAPAS dengan paratahanan. Terakhir bagi masyarakat hendaknya menerima para residivis penyalahgunaan narkotika secara lapang dada untuk kembali pada lingkungan masyarakat.

\section{DAFTAR PUSTAKA}

Bakri, N., \& Barmawi. (2017). Efektifitas Rehabilitasi Pecandu Narkotika melalui Terapi Islami di Badan Narkotika Nasional (BNN) Banda Aceh. Psikoislamedia: Jurnal Psikologi, 2(1). Retrieved from https://jurnal.ar-raniry.ac.id/index.php/Psikoislam/article/view/1827/1365

Ernawati, \& Tahir, H. (2017). Rehabilitasi Sosial terhadap Pecandu Narkoba Anak Dibawah Umur di Yayasan Kelompok Peduli Penyalahgunaan Narkotika dan Obat-Obatan Terlarang Makassar. Jurnal Tomalebbi: Jurnal Pemikiran, Penelitian Hukum, Pendidikan Pancasila Dan Kewarganegaraan, $I V(2)$. Retrieved from https://ojs.unm.ac.id/tomalebbi/article/view/3732

Franti, W. E. (2016). Tinjauan Yuridis tentang Rehabilitasi Sebagai Sanksi Tindakan terhadap Pelaku Penyalahgunaan Narkotika (Studi Kasus Di Pengadilan Negeri Mataram). Universitas Mataram. Retrieved from http://eprints.unram.ac.id/4099/

Harap, Z. (2002). Hukum Acara Peradilan Tata Usaha Negara (Edisi Revi). Jakarta: Rajawali Pers.

Hariwangi, A. P. K. A., Nahak, S., \& Sukadana, I. K. (2019). Implementasi Proses Rehabilitasi terhadap Penyalahguna Narkotika di Panti Rehabilitasi Yayasan Anargya Bali. Jurnal Analogi Hukum, 1(3). Retrieved from https://www.ejournal.warmadewa.ac.id/index.php/analogihukum/article/view/1766

Iskandar, D. (2019). Penegakan Hukum Narkotika. Jakarta: PT Elex Media Komputindo.

Kaligis, O. C., \& Associates. (2002). Narkoba dan Peradilannya di Indonesia: Reformasi Hukum Pidana 
Melalui Perundangan dan Peradilan. Bandung: Alumni.

Krisnawati, D., \& Utami, N. S. B. (2015). Pelaksanaan Rehabilitasi bagi Pecandu Narkotika Pasca Berlakunya Peraturan Bersama 7 (Tujuh) Lembaga Negara Republik Indonesia. Mimbar Hukum, 27(2). Retrieved from https://dev.jurnal.ugm.ac.id/jmh/article/download/15894/10503

Nasional, B. N. (n.d.). Mahasiswa dan Bahaya Narkotika. Jakarta.

Pananjung, L. K., \& Akbar, N. N. (2014). Peranan Badan Narkotika Nasional (BNN) dalam Penegakan Hukum terhadap Pelaku Penyalahgunaan Narkotika untuk Dirinya Sendiri (Pecandu) di Indonesia. Recidive, 3(3). Retrieved from https://jurnal.uns.ac.id/recidive/article/view/40528/26703

Purwani, S. P. M. E., Darmadi, A. A. N. Y., \& Putra, I. M. W. (2016). Implementasi Pengaturan Rehabilitasi Penyalah Guna Narkotika oleh Badan Narkotika Nasional Kota Denpasar. Kertha Patrika, 38(1). Retrieved from https://ojs.unud.ac.id/index.php/kerthapatrika/article/view/21535

Putra, R. A. (2016). Penerapan Sanksi Rehabilitasi terhadap Pengguna dan Korban Penyalahgunaan Narkotika (Studi Kasus Balai Rehabilitasi BNN Baddoka Makassar). Universitas Hasanuddin Makassar. Retrieved from https://core.ac.uk/download/pdf/77629827.pdf

Soeparman, H. (2000). Narkotika Telah Merubah Rumah Kami Menjadi Neraka. Jakarta: Departemen Pendidikan Nasional-Dirjen Dikti.

Sujatno, A. (2008). Pencerahan Dibalik Penjara dari Sangkar Menuju Sanggar Untuk Menjadi Mandiri. Jakarta.

Suyanto, S. (2013). Dampak Undang-Undang Informasi dan Transaksi Elektronik (UU ITE) terhadap Perubahan Hukum dan Sosial di dalam Masyarakat. Jurnal Ilmiah Widya, 1(1). Retrieved from https://e-journal.jurwidyakop3.com/index.php/jurnal-ilmiah/article/view/99/88 